\title{
Physiological quality, initial establishment and yield of wheat according to the seed treatment method ${ }^{1}$
}

\author{
Joice Aline Freiberg ${ }^{2}$, Marcos Paulo Ludwig ${ }^{3}$, \\ Leticia Decarli3 ${ }^{3}$, Eduardo Girotto ${ }^{3}$, Lucas Navarini ${ }^{3}$
}

\section{ABSTRACT}

New technologies are being incorporated to the seed treatment process, such as the use of products on industrial scale. This study aimed at evaluating the seed quality of wheat cultivars, as well as the influence of the seed treatment method on the establishment and yield of this crop. Seeds of the cultivars Jadeite 11, Quartzo and Tec Frontale were treated with the Spectro ${ }^{\circledR}$ fungicide (difenoconazole - $200 \mathrm{~mL} 100 \mathrm{~kg}^{-1}$ of seeds), Cruiser Opti ${ }^{\circledR}$ insecticide (thiamethoxam + lambdacyhalothrin - $200 \mathrm{~mL} 100 \mathrm{~kg}^{-1}$ of seeds) and Polifix G4 polymer (100 mL $100 \mathrm{~kg}^{-1}$ of seeds). A completely randomized design, with four replicates, was used. The treatments consisted of industrial treatment, on farm treatment with the same products and control. Germination, first germination count and moisture content tests were carried out immediately after the seed treatment and at 30,90 and 150 days of storage. Seedling emergence in beds was evaluated at 30,60 and 120 days of storage. Under a randomized block design, seedling emergence and grain yield were evaluated in the field in two sowing seasons. The conventional or industrial seed treatment methods do not reduce the physiological quality and emergence of highvigor seeds stored for 150 days, under controlled conditions of temperature and humidity. The conventional or industrial seed treatment with diphenoconazole + thiamethoxam + lambdacyhalothrin + polymer does not increase the wheat crop plant stand and grain yield.

KEYWORDS: Triticum aestivum L.; seedling emergence; germination; industrial seed treatment.

\section{INTRODUCTION}

The use of seeds with high physiological quality, along with the efficiency of fungicides and insecticides, is essential for high crop yields (Dan et al. 2010, Abati et al. 2014). The treatment of wheat

\section{RESUMO}

Qualidade fisiológica, estabelecimento inicial e produtividade de trigo em função do método de tratamento de sementes

Novas tecnologias estão sendo incorporadas ao processo de tratamento de sementes, como a aplicação de produtos em escala industrial. Objetivou-se avaliar a qualidade de sementes de cultivares de trigo, bem como a influência do método de tratamento de sementes no estabelecimento e produtividade dessa cultura. Sementes das cultivares Jadeite 11, Quartzo e Tec Frontale foram

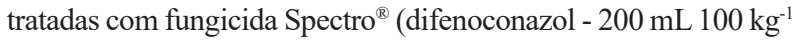
de sementes), inseticida Cruiser Opti ${ }^{\circledR}$ (tiametoxam + lambdacialotrina - $200 \mathrm{~mL} 100 \mathrm{~kg}^{-1}$ de sementes) e polímero Polifix G4 (100 mL $100 \mathrm{~kg}^{-1}$ de sementes). Utilizou-se delineamento inteiramente casualizado, com quatro repetições. Os tratamentos consistiram em tratamento industrial, tratamento convencional (on farm) com os mesmos produtos e testemunha. Foram conduzidos testes de germinação, primeira contagem e teor de água, realizados imediatamente após o tratamento das sementes e aos 30, 90 e 150 dias de armazenamento. Aos 30, 60 e 120 dias de armazenamento, foi avaliada a emergência em canteiros. Em campo, sob delineamento de blocos ao acaso, foram avaliadas a emergência e a produtividade de grãos, em duas épocas de semeadura. Os métodos de tratamento de sementes (convencional ou industrial) não reduzem a qualidade fisiológica e a emergência de sementes de alto vigor armazenadas por 150 dias, em condições controladas de temperatura e umidade. $\mathrm{O}$ tratamento de sementes com difenoconazol + tiametoxam + lambda-cialotrina + polímero, industrial ou convencional, não aumenta o estande de plantas e a produtividade da cultura do trigo.

PALAVRAS-CHAVE: Triticum aestivum L.; emergência de plântulas; germinação; tratamento industrial de sementes.

seeds with fungicides has facilitated the management of pathogens in seeds and soil, also increasing the seeds viability (Xue et al. 2017). Insecticides have also boosted the seedling development, by improving the seed physiological performance (Soares et al. 2014). The active ingredient thiamethoxam, for

1. Manuscript received in Sep./2017 and accepted for publication in Dec./2017 (http://dx.doi.org/10.1590/1983-40632017v4749214). 2. Universidade Federal de Santa Maria, Centro de Ciências Rurais, Departamento de Solos, Santa Maria, RS, Brasil.

E-mail: joice.freiberg@hotmail.com.

3. Instituto Federal de Educação, Ciência e Tecnologia do Rio Grande do Sul, Ibirubá, RS, Brasil.E-mails: marcos.ludwig@ ibiruba.ifrs.edu.br, leticia.decarli@ibiruba.ifrs.edu.br, eduardo.girotto@ibiruba.ifrs.edu.br, lucas.navarini@ibiruba.ifrs.edu.br. 
example, activates the plant defense mechanisms against abiotic stresses, such as high temperatures, low $\mathrm{pH}$ and water deficit, as well as against biotic stresses, such as lesions caused by pests (Almeida et al. 2014).

In addition to the use of products for a better performance of crops, new technologies have been incorporated into seed treatment, such as modern techniques for product application. The conventional technique using simple equipment for seed treatment on farms or in resales has been professionalized through industrial treatment (Platzen \& Peske 2013). The industrial seed treatment allows treating seeds with different chemical and biological formulations in the same processing line, facilitating the packaging and storage of seeds (Brzezinski et al. 2015). In addition, there is a greater operational efficiency with time and labor saving, reduction of intoxication risks, precise dosages of applied products, better coverage of products on the seed and guarantee of purchasing seeds with certified quality (França-Neto et al. 2015).

Wheat is one of the most important winter crops in southern Brazil, because, in addition to being a staple food in diets of the population, it has a major commercial importance. The Rio Grande do Sul and Paraná states account for roughly $90 \%$ of the national wheat production (Oliveira Neto \& Santos 2017). Nevertheless, few studies have investigated the effect of seed treatment on wheat crop yield. There is also a lack of information on the effects of seed treatments on the physiological quality of seeds under storage. In addition, it is necessary to analyze whether seed treatment (conventional or industrial) influences the physiological quality and yield of wheat crops. Therefore, this study assessed the seed quality of three wheat cultivars subjected to conventional and industrial treatments and stored for 150 days, as well as the influence of seed treatment on wheat crop development and yield.

\section{MATERIAL AND METHODS}

The study was conducted at the Instituto Federal de Educação, Ciência e Tecnologia do Rio Grande do Sul, in Ibirubá (28³9'22.1'S and $\left.53^{\circ} 6^{\prime} 43.2^{\prime \prime} \mathrm{W}\right)$, during the 2014 crop season. The site is located in the physiographic region of the medium plateau of the Rio Grande do Sul state (Brazil), where the climate is characterized as humid subtropical Cfa (Moreno 1961) and the soil is a Typic Hapludox (SSS 2014). Figure 1 shows the daily range of temperature and total precipitation during the experiment.

Seed lots of the wheat cultivars Jadeite 11, Quartzo and Tec Frontale were submitted to three treatments: control, industrial and conventional (on farm). Wheat seeds were treated with the Spectro $^{\circledR}$ fungicide (difenoconazole - $200 \mathrm{~mL}$ $100 \mathrm{~kg}^{-1}$ of seeds), Cruiser Opti ${ }^{\circledR}$ insecticide (lambda-cyhalothrin + thiamethoxam - $200 \mathrm{~mL}$ $100 \mathrm{~kg}^{-1}$ of seeds) and Polifix G4 polymer (100 mL

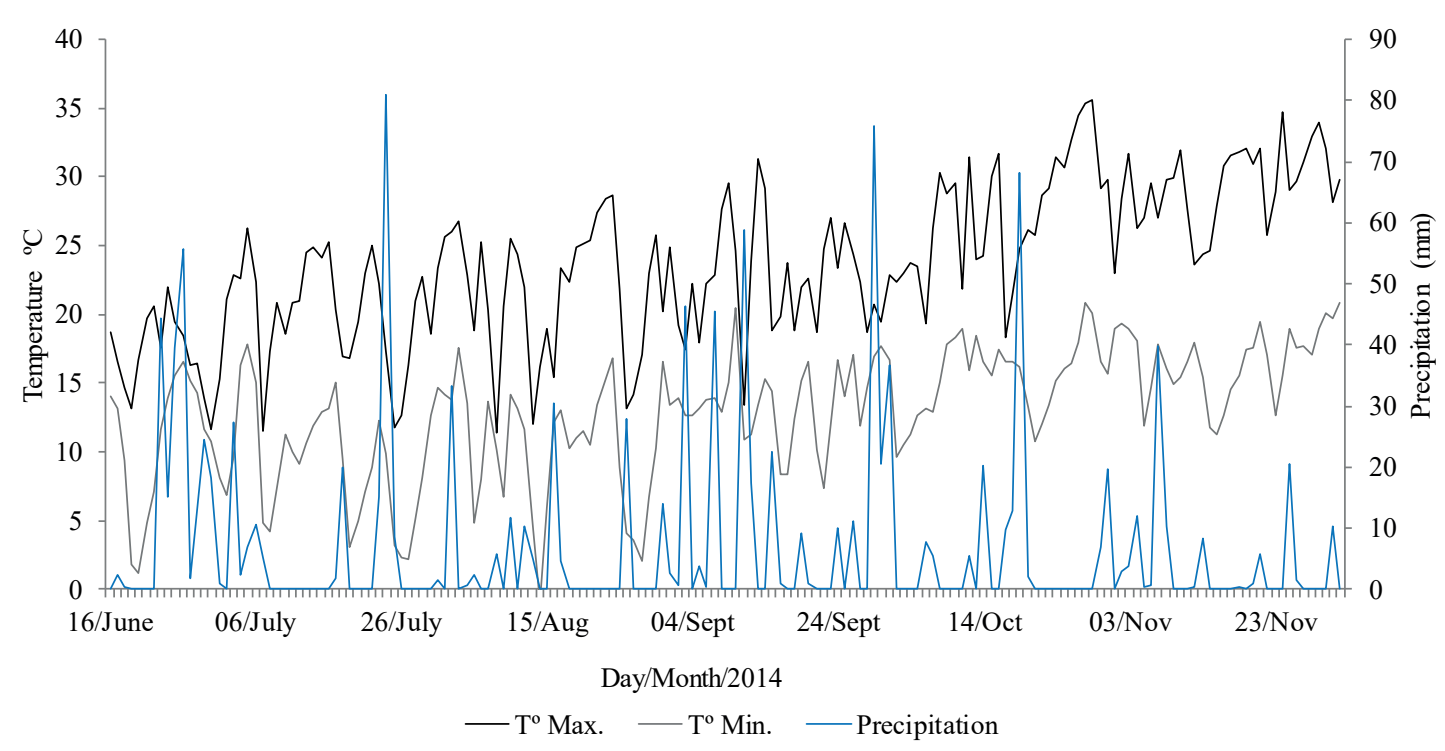

Figure 1. Precipitation $(\mathrm{mm})$ and maximum and minimum temperatures $\left({ }^{\circ} \mathrm{C}\right)$ during the wheat crop development, in Ibirubá, Rio Grande do Sul state, Brazil. Data were obtained from the automatic station of Ibirubá - A883, in 2014. 
$100 \mathrm{~kg}^{-1}$ of seeds). The industrial treatment was performed by the continuous flow process, in a Seed Mix VHS 10T equipment (Momesso brand). In the conventional treatment (on farm), plastic bags with a volumetric capacity of $10 \mathrm{~kg}$ were used, where $3 \mathrm{~kg}$ of seeds were shaken with $10 \mathrm{~mL} \mathrm{~kg}^{-1}$ of syrup used for industrial processing. Each repetition of the industrial and conventional treatments and control consisted of $3 \mathrm{~kg}$ of seeds, which were placed in paper bags and stored under controlled conditions of temperature $\left(20^{\circ} \mathrm{C}\right)$ and humidity $(60 \%)$ in the laboratory.

The laboratory experiment was conducted in a completely randomized design, with four replications. After the seed treatment and at 30, 90 and 150 days of storage, tests of germination, first germination count and moisture content were carried out, as it follows:

a) Germination test: four subsamples of 50 seeds were sown, totaling 200 seeds per repetition. The seeds were distributed on germitest paper moistened with distilled water at a ratio of 2.5 times the paper substrate mass. Afterwards, the paper rolls remained in a germination chamber at $20^{\circ} \mathrm{C}$. The evaluations were carried out at 8 days after sowing (DAS) (Brasil 2009) and the results were expressed as percentage of normal seedlings;

b) First germination count: held in conjunction with the germination test, and normal seedlings were counted at 4 days after the test began. The results were expressed as percentage of normal seedlings;

c) Seedling emergence in beds: seeds were sown by hand, with the distribution of 50 seeds $\mathrm{m}^{-1}$ ( $2 \mathrm{~cm}$ depth), in four sowing lines. The counts were made at 14 and 21 DAS, determining the number of seedlings emerged in the two central rows of each repetition. Seedling emergence was assessed at 30, 60 and 120 days after the treatment and storage of seeds. The experimental design was randomized blocks, with four replications, and the results were expressed as percentage of emerged seedlings;

d) Moisture content: determined by the oven method at $105^{\circ} \mathrm{C}$ (Brasil 2009).

The field experiment was conducted between June and November 2014.

The experimental design was randomized blocks, with four replications per treatment. The experiment was implemented on 20 June 2014, through direct seeding, succeeding a soybean crop. The plots consisted of 20 lines of $8 \mathrm{~m}$ long, spaced at $0.17 \mathrm{~m}$. Seeds were sown after the treatment and at 30 days of storage, and plant density was adjusted as recommended for the cultivars and seed lot germination rate.

The plant stand was determined at 14 and 21 DAS, by counting the number of emerged seedlings $\mathrm{m}^{-1}$, from the average of $2 \mathrm{~m}$ in each repetition. On physiological maturation, grain yield $\left(\mathrm{kg} \mathrm{ha}^{-1}\right)$ was assessed by harvesting 6 central lines of $3 \mathrm{~m}$, for a later grain trailing, weighing and moisture correction at $13 \%$.

The data were independently analyzed for each cultivar. The analysis of variance and hypothesis test were carried out to verify the significance of the treatment effect, time and interactions (treatment $\mathrm{x}$ time). When significant, the effect of the storage period was adjusted by regression. The means were compared by the Tukey test at $5 \%$, with the ExpDes.pt library in R (Ferreira et al. 2013).

\section{RESULTS AND DISCUSSION}

Overall, the moisture content of seeds showed a similar behavior among the cultivars, during the storage period. For the Jadeite 11 cultivar, there was a significant effect for treatment, time and interaction (Figure 2A, Table 1). Up to 90 days of storage, seeds

Table 1. Moisture content (\%) in seeds of the wheat cultivars Jadeite 11, Quartzo and Tec Frontale, using the industrial or conventional process of seed treatment and stored for 150 days.

\begin{tabular}{|c|c|c|c|c|}
\hline \multirow{2}{*}{ Treatment } & \multicolumn{4}{|c|}{ Storage period (days) } \\
\hline & 0 & 30 & 90 & 150 \\
\hline & \multicolumn{4}{|c|}{ Jadeite 11} \\
\hline Control & $12.6 \mathrm{Ab}^{*}$ & $12.0 \mathrm{Bb}$ & $11.8 \mathrm{BCc}$ & $11.6 \mathrm{Ca}$ \\
\hline Industrial & $13.3 \mathrm{Aa}$ & $12.8 \mathrm{Ba}$ & $12.8 \mathrm{Ba}$ & $11.9 \mathrm{Ca}$ \\
\hline Conventional & $12.2 \mathrm{Ac}$ & $12.3 \mathrm{Ab}$ & $12.3 \mathrm{Ab}$ & $11.8 \mathrm{Ba}$ \\
\hline Mean & \multicolumn{4}{|c|}{12.3} \\
\hline $\mathrm{CV}(\%)$ & \multicolumn{4}{|c|}{1.55} \\
\hline & \multicolumn{4}{|c|}{ Quartzo } \\
\hline Control & \multicolumn{4}{|c|}{$12.8 \mathrm{a}$} \\
\hline Industrial & \multicolumn{4}{|c|}{$12.5 \mathrm{~b}$} \\
\hline Conventional & \multicolumn{4}{|c|}{$12.7 \mathrm{ab}$} \\
\hline Mean & $13.0 \mathrm{~A}$ & $12.9 \mathrm{AB}$ & $12.6 \mathrm{~B}$ & $12.1 \mathrm{C}$ \\
\hline $\mathrm{CV}(\%)$ & \multicolumn{4}{|c|}{1.82} \\
\hline & \multicolumn{4}{|c|}{ Tec Frontale } \\
\hline Control & \multicolumn{4}{|c|}{$13.0 \mathrm{~b}$} \\
\hline Industrial & \multicolumn{4}{|c|}{$13.4 \mathrm{a}$} \\
\hline Conventional & \multicolumn{4}{|c|}{$13.2 \mathrm{ab}$} \\
\hline Mean & $13.9 \mathrm{~A}$ & $13.5 \mathrm{~B}$ & $13.1 \mathrm{C}$ & $12.3 \mathrm{D}$ \\
\hline CV (\%) & \multicolumn{4}{|c|}{1.72} \\
\hline
\end{tabular}


in the industrial treatment had a higher moisture content, differing significantly from those in the conventional treatment and control. There was a reduction of initial moisture content at the end of the storage period, when the industrial treatment showed the highest reduction percentage, in relation to the beginning of the storage period $(10.94 \%)$, followed by the control $(7.69 \%)$ and the conventional
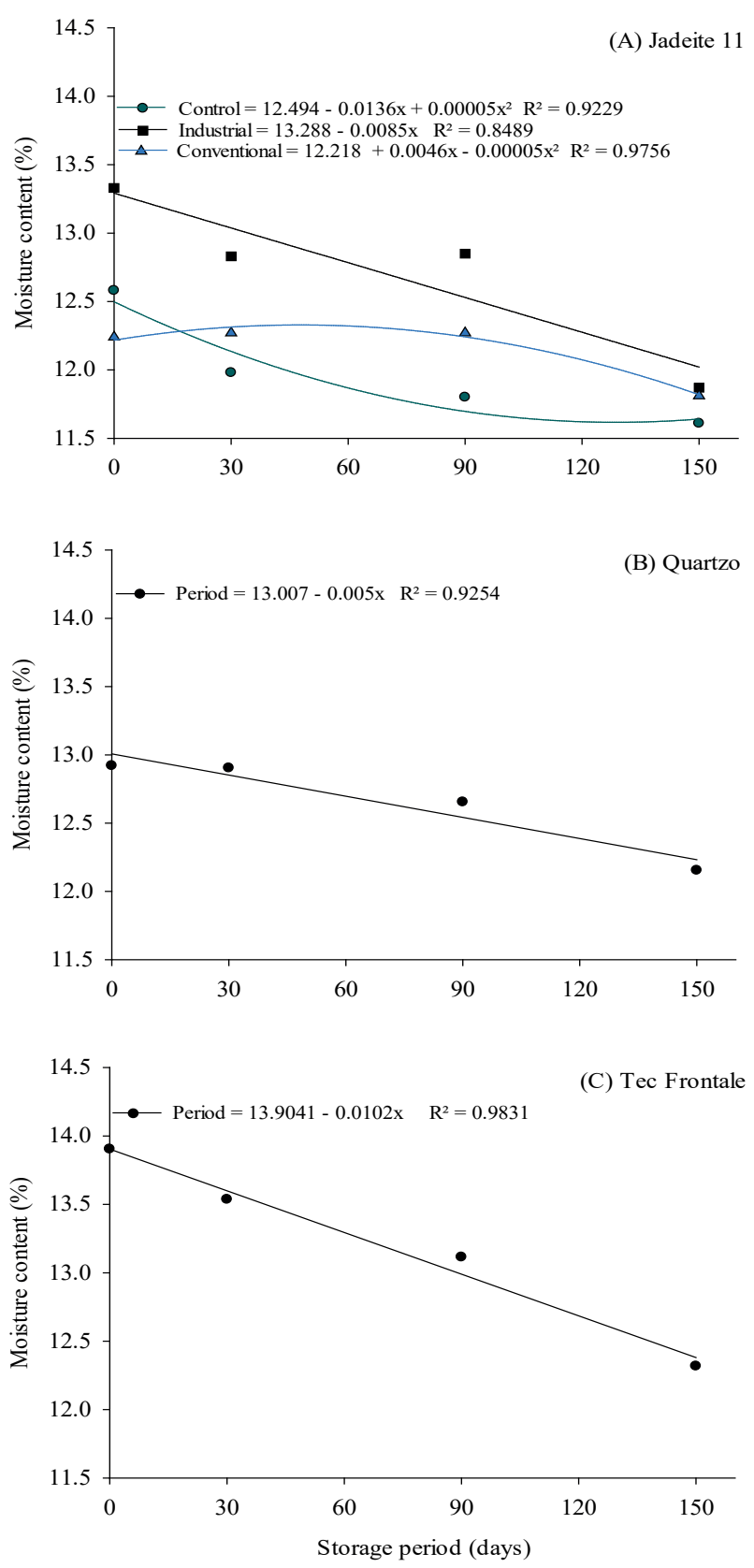

Figure 2. Moisture content in seeds of the wheat cultivars Jadeite 11 (A), Quartzo (B) and Tec Frontale (C) subjected to the industrial or conventional seed treatment and stored for 150 days. treatment $(3.57 \%)$. There were no differences between treatments at the end of the storage period (150 days). For the Quartzo cultivar, there was a significant effect of the treatment and storage period. The control presented the highest average moisture content $(12.8 \%)$, differing significantly from the industrial treatment $(12.5 \%)$ (Table 1$)$. In general, the storage period explained $92 \%$ of the moisture content variation in seeds (Figure 2B). For the Tec Frontale cultivar, there was also a significant effect of treatment and storage period (Figure 2C, Table 1). The moisture content in the control $(13.0 \%)$ was significantly lower than in the industrial treatment $(13.4 \%)$, and the linear model explained $98 \%$ of the moisture content variation in seeds, based on the storage time.

The industrial treatment increased the initial moisture content of seeds of the Jadeite 11 and Tec Frontale cultivars. However, the moisture content reduced along the storage period, due to the hygroscopic characteristic, which leads to water vapor exchanges between the seed and the environment, in order to establish a balance with the air relative humidity (Smaniotto et al. 2014). Environments with temperature and humidity control favor the seed physiological quality, whereas small changes in the moisture content reduce the metabolic activity and the deterioration rate of seeds (Cardoso et al. 2012). Contrary to differences observed between the treatments in this study, Freiberg et al. (2017) found no effect of treatment on the moisture content of wheat seeds treated with a combination of micronutrients, polymer, fungicide and insecticide, stored for 6 months under uncontrolled conditions of temperature and humidity.

The results for germination percentage of wheat seeds of the Jadeite 11 and Quartzo cultivars did not reveal an effect for seed treatment and storage period (Table 2). The first germination count showed an effect between treatment and storage period for both cultivars. For Jadeite 11, the control presented the lowest percentage of normal seedlings at time zero (Table 2). Likewise, Quartzo seeds in the control presented smaller germination percentages at the initial assessments (zero and 30 days), when compared to other storage periods. However, the physiological quality remained up to 150 days of storage, since the seeds were stored under controlled conditions of temperature and humidity. Tec Frontale seeds displayed germination percentages below the 
Table 2. First germination count and germination of three wheat cultivars subjected to industrial or conventional seed treatments with fungicide + insecticide + polymer and stored during 150 days.

\begin{tabular}{|c|c|c|c|c|c|c|c|c|}
\hline \multirow{3}{*}{ Treatment } & \multicolumn{4}{|c|}{ First germination count $(\%)$} & \multicolumn{4}{|c|}{ Germination (\%) } \\
\hline & \multicolumn{8}{|c|}{ Storage period (days) } \\
\hline & 0 & 30 & 90 & 150 & 0 & 30 & 90 & 150 \\
\hline & \multicolumn{8}{|c|}{ Jadeite 11} \\
\hline Control & $83 \mathrm{Bb}^{*}$ & $94 \mathrm{Aa}$ & $96 \mathrm{Aa}$ & $92 \mathrm{Aa}$ & \multicolumn{4}{|c|}{$97^{\mathrm{ns}}$} \\
\hline Industrial & $92 \mathrm{Aa}$ & $89 \mathrm{Aa}$ & $92 \mathrm{Aa}$ & $91 \mathrm{Aa}$ & \multicolumn{4}{|c|}{96} \\
\hline Conventional & $93 \mathrm{Aa}$ & $91 \mathrm{Aa}$ & $95 \mathrm{Aa}$ & $92 \mathrm{Aa}$ & \multicolumn{4}{|c|}{96} \\
\hline Mean & \multicolumn{4}{|c|}{92} & $96^{\text {ns }}$ & 96 & 97 & 97 \\
\hline $\mathrm{CV}(\%)$ & \multicolumn{4}{|c|}{4.94} & \multicolumn{4}{|c|}{3.25} \\
\hline & \multicolumn{4}{|c|}{ Quartzo } & \multicolumn{4}{|c|}{3.25} \\
\hline Control & $92 \mathrm{ABa}$ & $85 \mathrm{Bb}$ & $93 \mathrm{Aa}$ & $94 \mathrm{Aa}$ & \multicolumn{4}{|c|}{$95^{\mathrm{ns}}$} \\
\hline Industrial & $92 \mathrm{Aa}$ & $93 \mathrm{Aa}$ & $91 \mathrm{Aa}$ & $90 \mathrm{Aa}$ & \multicolumn{4}{|c|}{95} \\
\hline Conventional & $92 \mathrm{Aa}$ & $92 \mathrm{Aa}$ & $92 \mathrm{Aa}$ & $88 \mathrm{Aa}$ & \multicolumn{4}{|c|}{95} \\
\hline Mean & \multicolumn{4}{|c|}{91} & $96^{\mathrm{ns}}$ & 95 & 95 & 94 \\
\hline $\mathrm{CV}(\%)$ & \multicolumn{4}{|c|}{4.21} & \multicolumn{4}{|c|}{3.7} \\
\hline & \multicolumn{8}{|c|}{ Tec Frontale } \\
\hline Control & $52 \mathrm{Aa}$ & $55 \mathrm{Aa}$ & $56 \mathrm{Aa}$ & $46 \mathrm{Aa}$ & $66 \mathrm{Aa}$ & $68 \mathrm{Aa}$ & $64 \mathrm{Aa}$ & $62 \mathrm{Aa}$ \\
\hline Industrial & $52 \mathrm{Aa}$ & $49 \mathrm{Aa}$ & $47 \mathrm{Aab}$ & $23 \mathrm{Bb}$ & $66 \mathrm{Aa}$ & $60 \mathrm{Aa}$ & $58 \mathrm{Aa}$ & $41 \mathrm{Bb}$ \\
\hline Conventional & $57 \mathrm{Aa}$ & $48 \mathrm{ABa}$ & $42 \mathrm{Bb}$ & $21 \mathrm{Cb}$ & $65 \mathrm{Aa}$ & $59 \mathrm{Aa}$ & $53 \mathrm{Aa}$ & $38 \mathrm{Bb}$ \\
\hline Mean & \multicolumn{4}{|c|}{45} & \multicolumn{4}{|c|}{58} \\
\hline CV (\%) & \multicolumn{4}{|c|}{14.28} & \multicolumn{4}{|c|}{11.81} \\
\hline
\end{tabular}

threshold for wheat seeds (80 \%). Low-vigor seeds present lower contents of soluble protein, starch and soluble sugars, which, in turn, compromise the mobilization of reserves in the germination process (Henning et al. 2010). For the first germination count of Tec Frontale, there was a significant effect for the treatment, storage time and interaction. Seed treatment significantly affected the percentage of normal seedlings at 90 and 150 days of storage. In comparison to the control, there was a reduction of $25 \%$ in the percentage of normal seedlings in the conventional treatment at 90 days of storage and $50 \%$ and $54 \%$ for the industrial and conventional treatments, respectively, at 150 days of storage (Table 2).

Seed treatment showed an effect on germination only at 150 days of storage, when the industrial and conventional treatments significantly reduced the percentage of normal seedlings. Some authors suggest that the use of fungicides and insecticides in seed treatment may cause phytotoxicity, as reported by Vanin et al. (2011) in sorghum, Abati et al. (2014) in wheat and Brzezinski et al. (2015) in soybean. In this sense, Dan et al. (2010) also observed a reduced germination of soybean seeds treated with different insecticides and stored for 45 days under controlled conditions $\left( \pm 27{ }^{\circ} \mathrm{C}\right.$ and $\left.70 \% \mathrm{RH}\right)$, and the performance of seeds treated with thiamethoxam did not differ from those without treatment. Sorghum seeds stored in a cold chamber $\left(16{ }^{\circ} \mathrm{C}\right.$ and $50 \%$ $\mathrm{RH})$ also presented a reduction in the germination percentage after 30 days of storage, but no significant difference was observed between the control and the treatments with thiamethoxam, thiamethoxam + thiodicarb and thiamethoxam + fipronil (Vanin et al. 2011). For wheat, Hossen et al. (2014) reported higher germination percentages in seeds treated with thiamethoxam and thiamethoxam + carboxin + thiram. Similarly, the seed treatment with carboxin + thiram + thiamethoxam and polymer + carboxin + thiram + thiamethoxam did not compromise the physiological quality of wheat seeds stored for 120 days under uncontrolled conditions of temperature and humidity (Freiberg et al. 2017).

The results for emergence of stored seeds showed that the seed treatment did not affect the establishment of seedlings of the three wheat cultivars at 14 days after sowing (DAS), with $74 \%$ of seedlings for Jadeite 11, $71 \%$ for Quartzo and $38 \%$ for Tec Frontale (data not shown). In general, the wheat cultivars showed a reduction in the emergence potential along the storage period, with a significant 
effect at 21 DAS (Figure 3). For Jadeite 11, there was a significant reduction at 60 days (12\% reduction) and 120 days (19\% reduction). For Quartzo and Tec Frontale, there was also a significant reduction at 120 days ( $32 \%$ and $25 \%$, respectively), if compared to the initial emergence.

In bean seeds stored in a natural environment and in a dry chamber during 18 months, Zucareli et al. (2015) also observed a reduced emergence of seedlings, especially in seeds stored under uncontrolled conditions. After 240 days of storage, Brzezinski et al. (2015) also observed an emergence reduction in soybean seeds treated with fungicides, insecticides and nematicides, when compared to the pre-sown treatment. Similarly, Pereira et al. (2005) reported a significant reduction of the emergence rate of corn seeds treated with furazin + polymer, at 6 months after storage under environmental conditions. These authors suggest that coating the seeds with a polymer may reduce the water and oxygen entrance through the seed and compromise the germination process.

Similarly to the results of seedling emergence from stored seeds, in the field tests, the seed treatment did not influence the seedlings stand of Jadeite 11 at 14 and 21 DAS, and there was only an effect of storage period at 14 DAS (Table 3). This result was also observed at 14 and 21 DAS for Tec Frontale and Quartzo, with a higher percentage of seedlings stand at 30 days of storage. Several factors may have caused the reduction of the seedlings stand at sowing immediately after the seed treatment (time 0 ), namely genotypic and intrinsic characteristics of

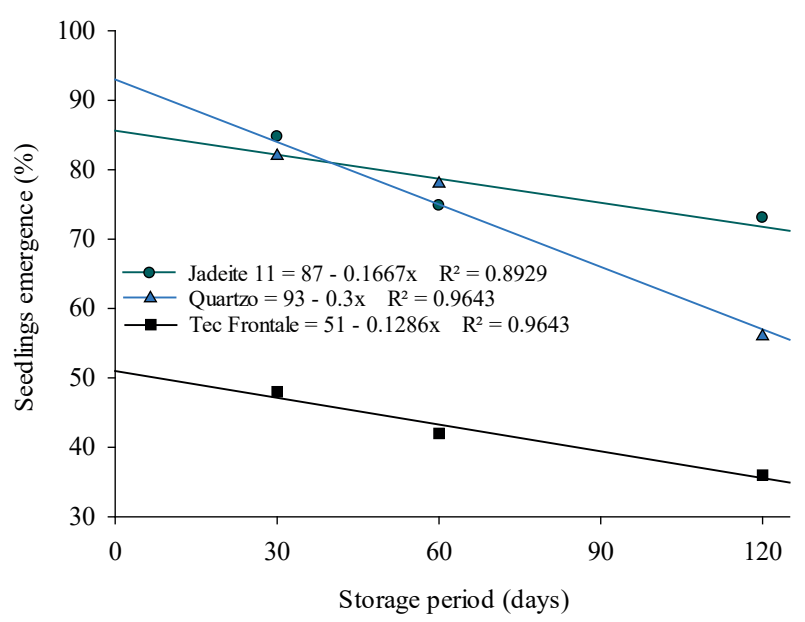

Figure 3. Seedlings emergence at 21 days after sowing of three wheat cultivars subjected to industrial or conventional seed treatment with fungicide + insecticide + polymer and stored for 120 days.

Table 3. Seedlings stand at 14 and 21 days after sowing (DAS) and yield of three wheat cultivars subjected to industrial or conventional seed treatment with fungicide + insecticide + polymer.

\begin{tabular}{|c|c|c|c|c|c|c|}
\hline \multirow{3}{*}{ Treatment } & \multicolumn{2}{|c|}{ Seedlings stand at 14 DAS } & \multirow{2}{*}{\multicolumn{2}{|c|}{$\begin{array}{c}\text { Seedlings stand at 21 DAS } \\
\text { Sowing period (DAT) }^{1}\end{array}$}} & \multicolumn{2}{|c|}{ Yield $\left(\mathrm{kg} \mathrm{ha}^{-1}\right)$} \\
\hline & & & & & & \\
\hline & 0 & 30 & 0 & 30 & 0 & 30 \\
\hline & \multicolumn{6}{|c|}{ Jadeite 11} \\
\hline Control & \multicolumn{2}{|c|}{$50^{\mathrm{ns}}$} & \multicolumn{2}{|c|}{$60^{\mathrm{ns}}$} & \multicolumn{2}{|c|}{$1,250^{\mathrm{ns}}$} \\
\hline Industrial & \multicolumn{2}{|c|}{55} & \multicolumn{2}{|c|}{63} & \multicolumn{2}{|c|}{1,264} \\
\hline Conventional & \multicolumn{2}{|c|}{64} & \multicolumn{2}{|c|}{62} & \multicolumn{2}{|c|}{1,143} \\
\hline Mean & $51 \mathrm{~B}$ & $61 \mathrm{~A}$ & $57^{\mathrm{ns}}$ & 67 & $1,097 \mathrm{~B}$ & $1,341 \mathrm{~A}$ \\
\hline CV $(\%)$ & \multicolumn{2}{|c|}{22.03} & \multicolumn{2}{|c|}{23.15} & \multicolumn{2}{|c|}{15.43} \\
\hline & \multicolumn{6}{|c|}{ Quartzo } \\
\hline Control & \multicolumn{2}{|c|}{$76 \mathrm{ab}^{*}$} & \multicolumn{2}{|c|}{$78^{\mathrm{ns}}$} & $1,331 \mathrm{Aa}$ & $1,118 \mathrm{Bab}$ \\
\hline Industrial & \multicolumn{2}{|c|}{$62 \mathrm{~b}$} & \multicolumn{2}{|c|}{71} & $977 \mathrm{Bb}$ & $1,229 \mathrm{Aa}$ \\
\hline Conventional & \multicolumn{2}{|c|}{$78 \mathrm{a}$} & \multicolumn{2}{|c|}{80} & $1,200 \mathrm{Aa}$ & $1,028 \mathrm{Bb}$ \\
\hline Mean & $64 \mathrm{~B}$ & $80 \mathrm{~A}$ & $71 \mathrm{~B}$ & $82 \mathrm{~A}$ & \multicolumn{2}{|c|}{1,147} \\
\hline \multirow[t]{2}{*}{ CV (\%) } & \multicolumn{2}{|c|}{16.49} & \multicolumn{2}{|c|}{16.24} & \multicolumn{2}{|c|}{7.67} \\
\hline & \multicolumn{4}{|c|}{ Tec Frontale } & \multirow{2}{*}{\multicolumn{2}{|c|}{$1,394^{\mathrm{ns}}$}} \\
\hline Control & \multicolumn{2}{|c|}{$60^{\mathrm{ns}}$} & \multicolumn{2}{|c|}{$65^{\mathrm{ns}}$} & & \\
\hline Industrial & \multicolumn{2}{|c|}{55} & \multicolumn{2}{|c|}{68} & & \\
\hline Conventional & & & & & & \\
\hline Mean & $48 \mathrm{~B}$ & $71 \mathrm{~A}$ & $56 \mathrm{~B}$ & $75 \mathrm{~A}$ & $1,134 \mathrm{~B}$ & $1,537 \mathrm{~A}$ \\
\hline CV (\%) & & & & & & \\
\hline
\end{tabular}

${ }^{1}$ Days after seed treatment: immediately after treatment $(0)$ and after storage of treated seeds (30 days). * Means followed by the same uppercase letter in the row and lowercase letter in the column do not differ by the Tukey test at $5 \%$. ${ }^{\text {ns }}$ Not significant. 
each cultivar, proper placement at sowing and abiotic factors, such as rainfall between the sowing and evaluation periods. In the first period after sowing, there was a high precipitation, which accumulated $240 \mathrm{~mm}$ of rain (Figure 1). On the other hand, in the period between sowing the treated seeds stored for 30 days and the emergence evaluation at 14 DAS, the accumulated rainfall was only $140 \mathrm{~mm}$.

The Jadeite 11 and Tec Frontale yields differed between the sowing periods and were significantly higher at 30 days after seed treatment and storage (Table 3). For these cultivars, the seed treatment did not affect the grain yield. For Quartzo, the industrial seed treatment significantly reduced the grain yield at time zero. However, after 30 days, there was a significant increase of $25 \%$ in yield, differing from the conventional treatment.

In general, a similar performance between the cultivars was observed in the field, regardless of the seed treatment method used, except for Quartzo. These results show the importance of adjusting the time of sowing, which, in this study, favored the initial seedlings stand, and later increased the grain yield, as also noted by Mielezrski \& Marcos Filho (2012) for pea. However, despite the lower physiological quality, Tec Frontale presented the highest average yield, contrary to the results found by Abati et al. (2017), where the high vigor of wheat seeds treated with imidacloprid and carboxy + thiram benefited the seedlings stand and grain yield. For Schuch et al. (2000), differences in vigor of black oat seeds affected only the initial plant growth, and the effects of seed vigor were reduced as the crop developed. Mondo et al. (2012) also suggest that the influence of seed vigor is reduced in developmental stages of the plants, and the plant response varies according to genotype and environmental relations.

The low wheat yield observed in this study is due to adverse environmental factors in 2014, in southern Brazil. Excessive humidity, torrential rains, low luminosity and high temperature range reduced the wheat average yield in the Rio Grande do Sul state to $1,330 \mathrm{~kg} \mathrm{ha}^{-1}$ (Conab 2014). Thus, the effect of seed treatment was not possibly expressed in the field.

The results show that, in general, seed treatment and seed treatment methods (conventional or industrial) did not affect the physiological quality of seeds. However, treated seeds with low physiological quality had their germination potential reduced with the advance of the storage period.
Similarly, seed treatment and treatment methods did not influence the seedlings emergence in beds and stand in the field, except for Quartzo at sowing immediately after seed treatment. Quartzo seeds treated by the industrial process reduced the potential for grain production at sowing immediately after seed treatment, but they showed a higher grain yield for sowing at 30 days after storage.

\section{CONCLUSIONS}

1. The treatment (difenoconazole + thiamethoxam + lambda-cyhalothrin + polymer) and the seed treatment methods (conventional or industrial) do not reduce the physiological quality of high-vigor seeds stored for 150 days under controlled conditions of temperature and humidity;

2. The treatment and seed treatment methods do not increase the wheat seedling emergence of seeds stored for 120 days;

3. The treatment and seed treatment methods do not increase the seedling stand and grain yield of the Jadeite 11 and Tec Frontale wheat cultivars.

\section{REFERENCES}

ABATI, J. et al. Seedling emergence and yield performance of wheat cultivars depending on seed vigor and sowing density. Journal of Seed Science, v. 39, n. 1, p. 58-65, 2017.

ABATI, J. et al. Treatment with fungicides and insecticides on the physiological quality and health of wheat seeds. Journal of Seed Science, v. 36, n. 4, p. 392-398, 2014.

ALMEIDA, A. S. et al. Treatment of rice seeds with thiamethoxam: reflections on physiological performance. Journal of Seed Science, v. 36, n. 4, p. 458-464, 2014.

BRASIL. Ministério da Agricultura, Pecuária e Abastecimento. Regras para análise de sementes. Brasília, DF: MAPA/ACS, 2009.

BRZEZINSKI, C. R. et al. Seeds treatment times in the establishment and yield performance of soybean crops. Journal of Seed Science, v. 37, n. 2, p. 147-153, 2015.

CARDOSO, R. B.; BINOTTI, F. F. S.; CARDOSO, E. D. Potencial fisiológico de sementes de crambe em função de embalagens e armazenamento. Pesquisa Agropecuária Tropical, v. 42, n. 3, p. 272-278, 2012.

COMPANHIA NACIONAL DE ABASTECIMENTO (Conab). Acompanhamento da safra brasileira de grãos: safra 2014/15. $3^{\circ}$ levantamento. Brasília, DF: Conab, 2014. 
DAN, L. G. M. et al. Qualidade fisiológica de sementes de soja tratadas com inseticidas sob efeito do armazenamento. Revista Brasileira de Sementes, v. 32, n. 2, p. 131-139, 2010 .

FERREIRA, E. B.; CAVALCANTI, P. P.; NOGUEIRA, D. A. ExpDes.pt: experimental design pacakge (Portuguese). R package version 1.1.2. 2013. Available at: <https://cran.r-project.org/web/packages/ExpDes.pt/ ExpDes.pt.pdf>. Access on: 27 Jul. 2017.

FRANÇA-NETO, J. B. et al. Adoção do tratamento industrial de sementes de soja no Brasil, safra 2014/15. Informativo Abrates, v. 25, n. 1, p. 26-29, 2015.

FREIBERG, J. A. et al. Physiological performance of wheat seeds treated with micronutrients and protection products during storage. Journal of Seed Science, v. 39, n. 2 , p. $182-188,2017$.

HENNING, F. A. et al. Composição química e mobilização de reservas em sementes de soja de alto e baixo vigor. Bragantia, v. 69, n. 3, p. 727-734, 2010.

HOSSEN, D. C. et al. Tratamento químico de sementes de trigo. Pesquisa Agropecuária Tropical, v. 44, n. 1, p. 104-109, 2014.

MIELEZRSKI, F.; MARCOS FILHO, J. Potencial fisiológico de sementes armazenadas e desempenho de plantas de ervilha. Revista Brasileira de Sementes, v. 34, n. 4, p. 665-677, 2012.

MONDO, V. H. V. et al. Vigor de sementes e desempenho de plantas de milho. Revista Brasileira de Sementes, v. 34, n. 1, p. $143-155,2012$.

MOREnO, J. A. Clima do Rio Grande do Sul. Porto Alegre: Secretaria de Agricultura, 1961.
OliveirA NETO, A. A.; SANTOS, C. M. R. (Orgs.). A cultura do trigo. Brasília, DF: Conab, 2017.

PEREIRA, C. E. et al. Qualidade fisiológica de sementes de milho tratadas associadas a polímeros durante o armazenamento. Ciência e Agrotecnologia, v. 29, n. 6, p. 1201-1208, 2005.

PLATZEN, H.; PESKE, S. Tratamento de sementes: ênfase em inseticida. Seed News, ano XVII, n. 5, p. 22-23, 2013.

SCHUCH, L. O. B. et al. Vigor de sementes e análise de crescimento de aveia preta. Scientia Agricola, v. 57, n. 2, p. 305-312, 2000.

SMANIOTTO, T. A. S. et al. Qualidade fisiológica das sementes de soja armazenadas em diferentes condições. Revista Brasileira de Engenharia Agrícola e Ambiental, v. 18, n. 4, p. 446-453, 2014.

SOARES, V. N. et al. Physiological performance of rice seeds treated with thiamethoxam or rhizobacteria under different temperatures. Journal of Seed Science, v. 36, n. 2 , p. 186-193, 2014.

SOIL SURVEY STAFF (SSS). Keys to soil taxonomy. 12. ed. Washington, DC: USDA, 2014.

VANIN, A. et al. Tratamento de sementes de sorgo com inseticidas. Revista Brasileira de Sementes, v. 33, n. 2, p. 299-309, 2011.

XUE, A. G. et al. Effect of seed treatment with novel strains of Trichoderma spp. on establishment and yield of spring wheat. Crop Protection, v. 96, n. 1, p. 97-102, 2017.

ZUCARELI, C. et al. Qualidade fisiológica de sementes de feijão carioca armazenadas em diferentes ambientes. Revista Brasileira de Engenharia Agrícola e Ambiental, v. 19, n. 8, p. 803-809, 2015. 